\title{
Metáforas e domínios narrativos numa perspectiva da Linguística de Corpus $^{1}$ \\ Metaphors and narrative domains on an approach of Corpus Linguistics
}

Heberth Paulo de Souza*

RESUMO: Neste artigo, desenvolve-se uma abordagem da metáfora no escopo da cognição humana, utilizando os pressupostos teóricos da Linguística Cognitiva no âmbito das representações mentais e aplicando-os à descrição da articulação textual. Para alcançar esse intento, centramo-nos em alguns postulados do final do século XX que a consideram como um recurso de facilitação do raciocínio, através do qual conceitos mais complexos são elaborados na forma de conceitos mais simples. Considera-se também que a metáfora é um fenômeno presente em todos os níveis da comunicação, não se restringindo a algumas áreas $\mathrm{e}$ atividades do conhecimento humano. Baseando-se especialmente na Teoria dos Espaços Mentais, de Fauconnier (1994), e na Teoria da Mesclagem Conceitual, de Fauconnier e Turner (1994), a pesquisa desenvolveu-se sobre um corpus pequenomédio, descrevendo o papel que a metáfora exerce na articulação textual. Com o suporte dos recursos eletrônicos do programa WordSmith Tools $₫$, obteve-se uma sistematização de dados quantitativos para se proceder à pesquisa qualitativa, a partir de onde foi possível alcançar os resultados apresentados na tese de doutorado que deu origem a este artigo. Entre estes, destaca-se a constatação de que, subjacente à estruturação textual dos exemplares do nosso corpus, bem como em outros tipos textuais que também foram submetidos à análise, existe uma forma de organização de elementos típica do processo de narração, com a identificação de

\begin{abstract}
In this paper an approach to metaphor, in the scope of human cognition, is developed, taking into account theoretical assumptions of Cognitive Linguistics within the ambit of mental representations, and having them applied to a description of textual articulation. In order to achieve this goal, we focused on a few late twentiethcentury postulates. Metaphor is thus assumed to be a resource used to facilitate reasoning by means of which more complex concepts are elaborated in terms of more simple ones. Metaphor is also considered as a phenomenon present in all levels of communication, not being restricted to specific areas and activities of human knowledge. Based especially on both Mental Spaces Theory, by Fauconnier (1994), and on Conceptual Blending Theory, by Fauconnier and Turner (1994), the research was developed with the use of a small-mediumsize corpus, describing the role that metaphor plays in textual articulation. With the aid of the electronic tool WordSmith Tools $\subset$ it was possible to obtain a systematization of quantitative data in order to proceed to the qualitative research, from where the results in the original doctoral thesis were made available. It thus becomes clear that, underlying the textual structuring of the samples of our corpus, as well as in other textual types that were also submitted to analysis, there is a pattern of organization considered as typical of the narrative process that includes the identification of information relating to time, space and characters,
\end{abstract}

\footnotetext{
1 Artigo-síntese de tese de doutorado defendida pelo POSLIN - Programa de Pós-graduação em Estudos Linguísticos da UFMG, em 27/08/2010, intitulada "A metáfora e a formação de esquemas narrativos em textos escritos de língua portuguesa".

* Doutor em Linguística pela UFMG - Universidade Federal de Minas Gerais. Professor de Língua Portuguesa e Metodologia Científica no IPTAN - Instituto de Ensino Superior Presidente Tancredo de Almeida Neves (São João del-Rei - MG).
} 
informações relacionadas a tempo, espaço e personagens, considerando-se a inter-relação do nível metafórico e do não metafórico.

PALAVRAS-CHAVE: Metáfora. Narrativa. Espaços Mentais. Mesclagem Conceitual. Corpus linguístico. considering the interrelationship between metaphorical and nonmetaphorical levels.

KEYWORDS: Metaphor. Narrative. Mental Spaces. Conceptual Blending. Linguistic corpus.

\section{Introdução}

Desde que foi evidenciada no campo dos estudos da Filosofia e da linguagem, a metáfora vem intrigando vários pesquisadores em virtude de algumas características que a vinculam a fenômenos diversos, tais como: a importância da metáfora na determinação de aspectos estilísticos do discurso, o papel da metáfora na oratória e na retórica, o papel das construções metafóricas na determinação do caráter literário ou não literário de um texto, a relação entre metáfora e o modo de pensar do ser humano, a inteligibilidade das ideias contidas num texto em função do seu nível metafórico, entre outros. Não foi por outro motivo que, a partir mesmo dos filósofos da Antiguidade clássica, a metáfora vem sendo abordada, ao longo de mais de vinte séculos, sob as mais variadas perspectivas, revelando-se sempre novas facetas desse fenômeno da linguagem, as quais se complementam, alternam-se e geram novas pesquisas sobre o tema.

Na segunda metade do século XX, os estudos da linguagem assistiram ao advento de uma área que finalmente se consolidou como distinta de outros ramos da Linguística e que tem como preceito básico o estudo do funcionamento da mente humana: a Linguística Cognitiva, que, embora também apresente diferentes modos de tratar os processos mentais que subjazem à comunicação humana, alcançou um desejável nível de solidez através da gramática cognitiva de Langacker (1987 e 1991). Nesses dois volumes, o autor descreve sistematicamente a relação existente entre a linguagem verbal e o modo como processamos as noções expressas pelo signo linguístico, proporcionando entendimentos e análises que até então ficavam circunscritas à nossa intuição como usuários e analistas da linguagem.

Paralelamente aos postulados da gramática cognitiva de Langacker, num outro contexto de estudos, Gilles Fauconnier desenvolvia importantes pesquisas sobre os espaços mentais, categorias de ordem cognitiva que também viriam a proporcionar entendimento mais conciso sobre a metáfora e outros fenômenos da linguagem, consolidando-se com a 
publicação de $1994^{2}$. A identificação desses domínios cognitivos (espaços mentais), cujas características serão descritas neste trabalho, acrescentou à Linguística Cognitiva - mais especificamente à Semântica Cognitiva - um arcabouço teórico e um modelo de análise que adiantaram demasiadamente nossa compreensão da inter-relação entre linguagem e cognição humana.

Além da metáfora, vários outros fenômenos e elementos linguísticos puderam ser descritos com a fidedignidade de quem pretende conferir à linguagem verbal um status não fragmentado e não desvinculado de outras habilidades humanas. Nesse contexto, beneficiaram-se também sobremaneira da teoria dos espaços mentais as pesquisas que vinham sendo empreendidas em torno da narrativa - não em sua clássica abordagem dentro de gêneros textuais, mas também enquanto um fenômeno da cognição humana. Nesse sentido, Turner (1996) realizou um empreendimento de fundamental importância, demonstrando que a mente do ser humano é literária (entenda-se "narrativa") por excelência; em outras palavras, mesmo quando não estamos lidando diretamente com uma narrativa clássica, nosso modo de pensar é tipicamente narrativo.

Não é por outro motivo que Fauconnier e Turner estabeleceram uma parceria em suas pesquisas que vem rendendo, até recentemente, muitas publicações conjuntas ${ }^{3}$. A partir de Fauconnier e Turner (1994), a Semântica Cognitiva se viu enriquecida com o estabelecimento da teoria da mesclagem conceitual, um modelo de análise que discrimina a inter-relação de diferentes espaços mentais na produção do sentido, que se aplica especialmente no caso de sentidos emergentes, ou seja, ausentes nos espaços de origem, que se revelam numa sequência enunciativa em função principalmente de condições contextuais.

Até este ponto, vimos en passant o surgimento de duas importantes teorias que não foram criadas propriamente no bojo dos estudos de corpora, mas a nossa pesquisa tenciona justamente empreender uma análise no esteio da Semântica Cognitiva utilizando-se dos benefícios proporcionados por um segmento que nos capacita a lidar com um grande número de textos, cruzar dados quantitativos que proporcionem importantes questionamentos e hipóteses de cunho qualitativo e cujos resultados sejam atinentes a enunciados autênticos.

\footnotetext{
2 Trata-se da publicação de Fauconnier (1994), obra que, na verdade, tinha sido publicada dez anos antes em língua francesa (FAUCONNIER, 1984), mas que atingiu patamares acadêmicos mais amplos a partir da publicação mais recente em inglês.

${ }^{3}$ Entre elas, Turner e Fauconnier (1995), Fauconnier e Turner (1996, 1998, 2000 e 2002).
} 
Para atingir esse objetivo, será feita uma sucinta explanação sobre essas teorias semântico-cognitivas para, posteriormente, apresentarmos a abordagem realizada via análise de corpus.

\section{A teoria dos espaços mentais e da mesclagem conceitual}

Fauconnier (1994) caracteriza os espaços mentais como domínios cognitivos que são ativados por certas expressões linguísticas e por alguns mecanismos de reconhecimento de elementos em diferentes campos (psicológico, cultural, histórico, ficcional etc.). A dinâmica que envolve os espaços mentais se resume no seguinte: a referência a um determinado elemento "a" situa-o num domínio cognitivo específico, chamado domínio-fonte. Através de um conector, que pode ser uma expressão linguística ou um outro mecanismo construtor de espaço, as características desse elemento "a" são projetadas para um elemento "b" pertencente a outro domínio cognitivo, chamado domínio-alvo. Esquematicamente, temos o seguinte:

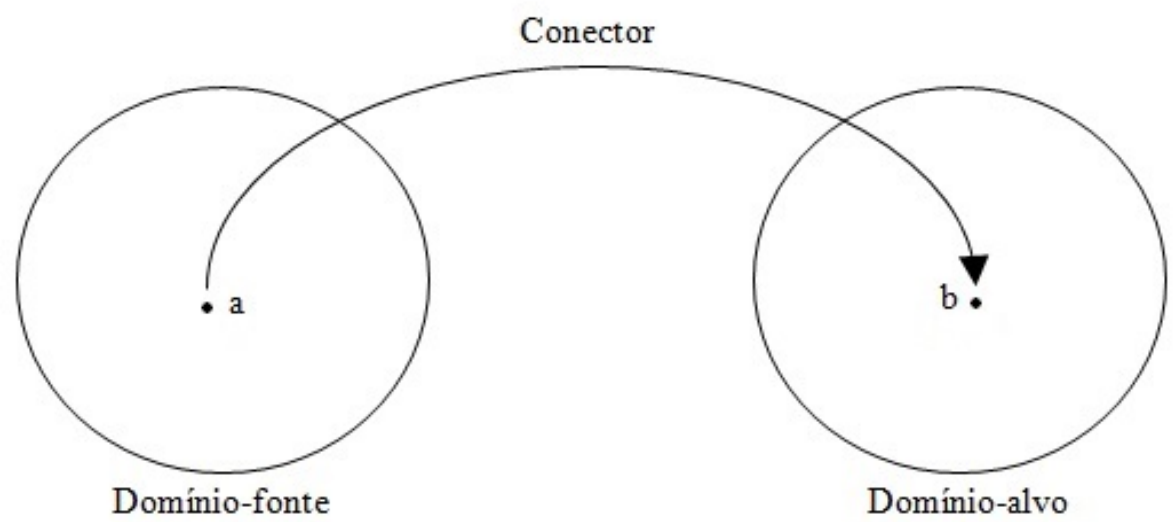

Figura 1 - Esquema de projeção de elementos entre espaços mentais diferentes

O modelo acima é o princípio de uma complexa rede de relações entre domínios cognitivos que se processa na linguagem. Durante uma prática comunicativa qualquer, ativamos vários espaços mentais e inter-relacionamos elementos de vários desses espaços, estabelecendo uma rede de projeções tal que a linguagem se configura como um intrincado emaranhado de elementos, domínios e projeções. Esse modelo nos permite entender que a linguagem humana é um jogo de projeções por excelência. Fazemos analogias o tempo todo, sendo tais o fundamento do nosso raciocínio em várias situações, desde a comunicação corriqueira mais elementar até as construções consideradas mais complexas. 
Vejamos uma aplicação desse modelo de Fauconnier à sequência linguística que destacamos no pequeno texto abaixo:

(1) Dois carregadores estão conversando e um diz: "Se eu fosse Presidente da República, eu só acordava lá pelo meio-dia, depois ia almoçar lá pelas três, quatro horas. Só então é que eu ia fazer o primeiro carreto."

Nesse caso, o domínio-fonte engloba as informações referentes ao mundo do carregador (pobreza, necessidade de trabalhar, dificuldades de sobrevivência etc.), enquanto o domínio-alvo abarca os dados relativos à vida do Presidente da República (marcada pelo poder, regalias etc.). Para a compreensão do sentido do trecho, as informações do domínio do carregador são transpostas para o domínio do Presidente da República, e funciona como conector, nesse caso, a expressão introdutora da contrafactualidade, "se eu fosse". Nesse processo, toda a noção relativa aos comportamentos e estilo de vida do carregador é compreendida no âmbito de outro domínio, o do Presidente da República. Esquematicamente:

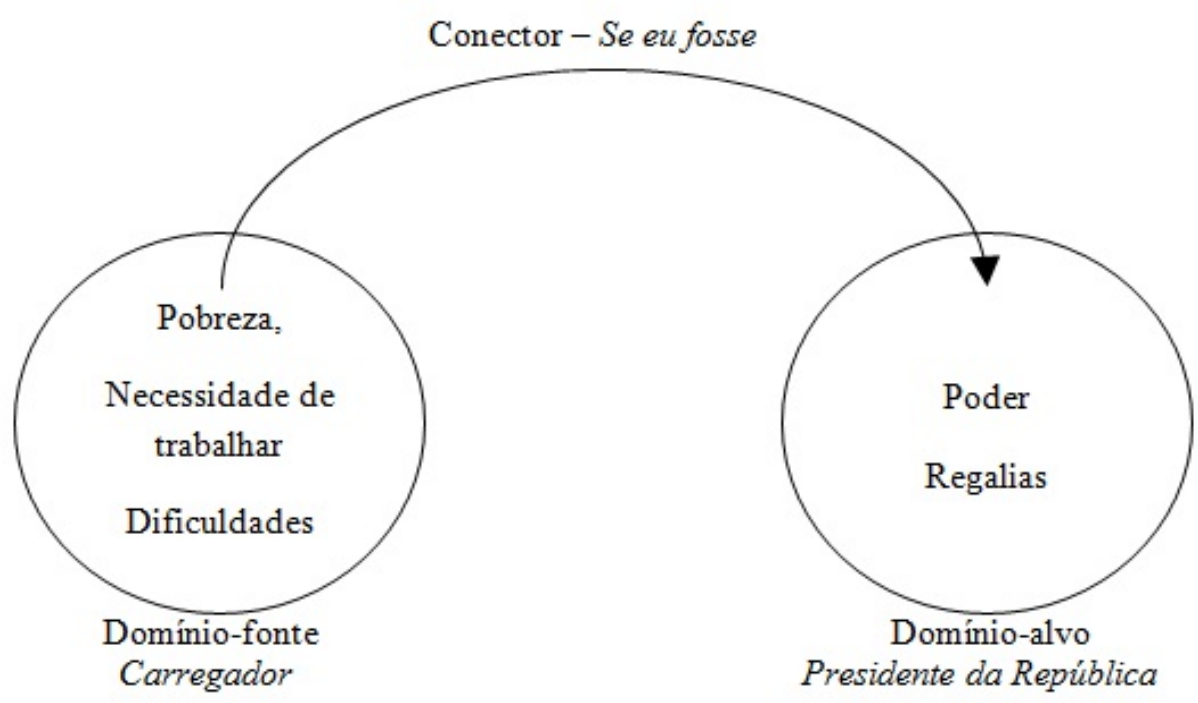

Figura 2 - Esquema de projeção de informações entre domínios diferentes

O modelo descritivo de Fauconnier é capaz de explicar como funciona a mente humana diante de situações em que operamos vários tipos de analogias, mas ele não é suficiente para explicar a seletividade que envolve o processo, ou seja, a imagem de um carregador que possui certas regalias de um Presidente da República, ou a imagem de um

\footnotetext{
${ }^{4}$ Transcrito de prova de Língua Portuguesa de Vestibular da Unicamp - SP. Grifo nosso.
} 
Presidente da República que precisa fazer carreto. Isso vai concretizar-se mais tarde com a teoria da mesclagem conceitual, como veremos adiante. De toda forma, a teoria dos espaços mentais veio esclarecer como somos capazes de lidar com elementos de diferentes domínios cognitivos, projetando informações de um espaço para outro.

Esse modelo de projeção de informações de um domínio-fonte para um domínio-alvo atende a um princípio mais geral, o Princípio de Identificação, também chamado por Fauconnier (1997, p. 41) de Princípio de Acesso, segundo o qual se afirma o seguinte:

Se dois objetos $a$ e $b$ se ligam por uma função pragmática $\mathrm{F}(b=\mathrm{F}(a))$, então uma descrição de $a\left(d_{a}\right)$ pode ser usada para identificar sua contraparte $b$.

Por "função pragmática" entende-se o estabelecimento de "ligações entre objetos de natureza diferente por razões psicológicas, culturais ou localizadamente pragmáticas" ${ }^{5}$, noção bem desenvolvida por Nunberg (1978). Em outras palavras, existem razões de natureza extralinguística que justificam o fenômeno da projeção, e esse é um ponto crucial para o nosso estudo sobre metáforas. No caso acima, não é por acaso que o carregador estabelece a analogia com o Presidente da República; existe uma série de características sobre esta entidade que motivam o processo de analogia.

O modelo de representação da mesclagem conceitual é uma evolução dos estudos realizados sobre os espaços mentais, tanto que o suporte daquela são os mesmos domínios cognitivos descritos anteriormente. A mesclagem conceitual surge como uma teoria que explica a dinâmica funcional dos espaços, com a vantagem de incluir outros domínios - indo além da simples relação entre domínios fonte e alvo -, o que enriquece sobremaneira a compreensão sobre o processamento do sentido.

Fauconnier e Turner (2002), fazendo uso de exemplos bem práticos, apresentam muitos detalhes sobre o processo de mesclagem, enfatizando especialmente os elementos que compõem essa rede de integração conceitual. E especialmente em Fauconnier e Turner $(1996)^{6}$ é apresentada a ideia de que os padrões gramaticais de uma língua refletem, em grande parte, as mesclagens conceituais e o processo de integração de eventos. Daí a noção de

\footnotetext{
5 No original: "links between objects of a different nature for psychological, cultural, or locally pragmatic reasons" (FAUCONNIER, 1994, p. 3).

6 Uma versão expandida desse trabalho se encontra em: $<$ http://markturner.org/centralprocess.WWW/centralprocess.html>. Acesso em: 12 set. 2014.
} 
que o estudo da linguagem verbal é a chave para se alcançar o entendimento dos processos da cognição humana.

Outra inovação no modelo da mesclagem conceitual é a identificação do espaço da mescla como uma estrutura emergente, sinalizado com um quadriculado. Nos estudos cognitivos em geral, a noção desse tipo de estrutura é de fundamental importância para a compreensão de vários fenômenos. Nesse aspecto, vale ressaltar a importância de trabalhos como o de Grady, Oakley e Coulson (1997), que mostram como uma sentença do tipo "aquele cirurgião é um açougueiro" apresenta uma série de significados emergentes, provando que o espaço da mescla não é um espaço de mera composicionalidade semântica.

Com essas modificações, o modelo utilizado para representar o processo de mesclagem é o que se mostra abaixo, no qual figuram o espaço de entrada 1 e o espaço de entrada 2 como domínios que apresentam elementos mapeados entre si, além do espaço genérico e o espaço emergente da mescla:

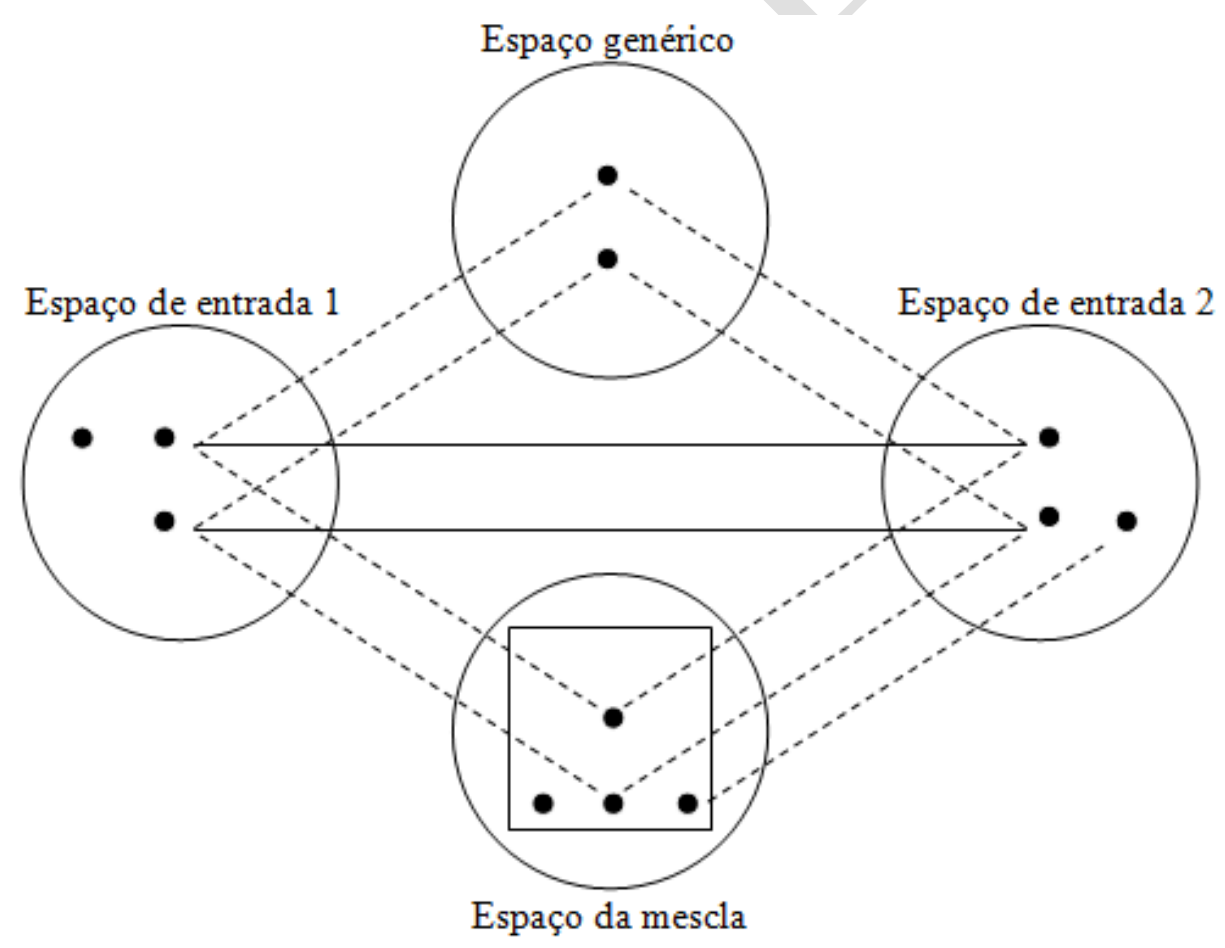

Figura 3 - Modelo de representação do processo de mesclagem conceitual

Observe-se que, pelo esquema apresentado acima, os espaços de entrada podem encerrar elementos que não são projetados para o espaço da mescla, bem como elementos projetados podem não apresentar uma contraparte no outro espaço de entrada. E, ainda, há 
informações que emergem no espaço da mescla sem que tenham provindo de qualquer espaço de entrada (sentido emergente).

\section{A metáfora no contexto da Linguística Cognitiva}

Na segunda metade do século XX, vários estudos são empreendidos com foco no aspecto cognitivo. Essa característica se faz sentir em várias áreas do conhecimento humano, e não ocorre diferente em relação aos estudos da linguagem. Essa preocupação com o aspecto mentalista da linguagem vem desembocar nos estudos cognitivos, e com o advento da Gramática Cognitiva de Langacker esse espaço se consolida, desenvolvendo-se cada vez mais nos últimos decênios.

Em 1979, é amplamente difundida uma noção explicativa sobre o funcionamento da linguagem humana através de um clássico artigo de Michael Reddy. Segundo o autor, as palavras são concebidas como contêineres das ideias, e estas são transmitidas como que passando por um tubo de indivíduo para indivíduo. Dessa forma, as palavras podem ser entendidas como vazias de sentido ou plenas de significado, e o processo de transmissão de ideias pode ser entendido como susceptível a quaisquer vicissitudes típicas da passagem de objetos por um canal. É sobre essa noção que Reddy desenvolve o que ele denomina "metáfora do tubo" (conduit metaphor) ${ }^{7}$.

Em 1980, foi publicada uma obra que revolucionou o pensamento acerca da metáfora, inclusive alargando a sua concepção e relacionando-a à experiência corporal, cultura, usos e costumes dos indivíduos. Lakoff e Johnson (1980) defendem a ideia de que as metáforas não são recursos especiais de linguagem, como era costume supor, específicos da linguagem literária ou retórica, mas fazem parte da linguagem corriqueira. E, mais do que isso, a metáfora também está presente no pensamento e nas ações humanas, não sendo tão somente um aspecto da linguagem verbal; nosso sistema conceitual é metafórico por natureza. $\mathrm{O}$ homem pensa, age e comunica através de metáforas.

Os autores apresentam metáforas fundamentais, a partir das quais muitos elementos comunicativos como expressões linguísticas, gestos e posturas são criados, como "para cima é bom; para baixo é ruim", "argumentar é lutar", "tempo é dinheiro", "ideias são objetos", "palavras são contêineres", "abstrato é concreto", "seres abstratos são entidades físicas",

\footnotetext{
${ }^{7}$ Cf. Reddy (1979).
} 
“comunicar é enviar" etc. A título de exemplo, a primeira metáfora orientacional desta lista se manifesta através de uma série de expressões linguísticas ( $A$ bolsa de valores fechou em alta, Fulano está no fundo do poço, Beltrano está em alto astral, Ela se encontra deprimida (= em depressão), Subir na vida, Chegar ao topo da carreira, Fazer parte do alto escalão, Hoje estou meio down, Os planos caíram por terra), de gestos (polegar apontado para cima para indicar estado bom, polegar apontado para baixo para indicar estado ruim; referência ao céu para indicar o paraíso religioso, referência ao subterrâneo para indicar o inferno) e de posturas (ficar de cabeça erguida é bom, ficar cabisbaixo é ruim). Uma importante ideia defendida por Lakoff e Johnson é que não existe, a rigor, nenhum tipo de necessidade humana para se operarem tais conceitualizações; o que existe, e que justifica a concepção de uma ideia em termos de outra, é o apego à cultura da sociedade em que o indivíduo se encontra, além das suas experiências corporais. A metáfora orientacional que foi explicada acima, por exemplo, pode ser justificada pela própria experiência do ser humano, em seu primeiro ano de vida, ao tentar vencer a força gravitacional e manter-se de pé, em postura ereta.

É importante ressaltar que esses esquemas metafóricos não são propriamente universais semânticos, como poderia supor algum radical dentro dessa teoria. Trata-se, na verdade, de tendências de conceitualização manifestadas pelo ser humano de acordo com fatores ligados à sua vivência, cultura, constituição biológica. Portanto, apresentam um grau de uniformidade bastante considerável na espécie humana.

$\mathrm{O}$ advento da teoria sobre a metáfora conceitual impulsionou os estudos desse fenômeno sob a ótica da cognição humana e constituiu um grande impacto provocado sobre uma tradição de muitos séculos que encarava a metáfora como uma relação de simples-troca de expressões - com ressalva, obviamente, para importantes estudos empreendidos por filósofos desde alguns séculos passados que adiantam essa postura que veio consolidar-se ao final do século passado.

\section{A metáfora analisada sob o prisma da Linguística de Corpus}

Nas últimas décadas, têm crescido em larga escala os estudos linguísticos baseados em dados autênticos de linguagem, seja na modalidade oral ou escrita. Os avanços na área de Informática vêm proporcionando ganhos incomensuráveis nesse aspecto, fazendo com que a Linguística de Corpus enriqueça-se cada vez mais em termos de consistência técnica, teórica e metodológica, impulsionando o nível das pesquisas em todas as áreas da linguagem. 
No Brasil, pesquisas nesse campo têm alcançado muito êxito, principalmente com a criação de programas específicos para análises linguísticas, como os etiquetadores, concordanciadores etc. Juntamente a isso, a montagem e o incremento de extensos bancos de textos disponíveis para análise - os corpora - têm proporcionado às nossas pesquisas enormes vantagens.

Berber Sardinha (2004) oferece uma boa visão desse tipo de pesquisa, reunindo os aspectos fundamentais para os estudos baseados em corpora, desde o histórico sobre essa área, a descrição de bancos de textos, até os detalhes de ordem técnica para utilização de ferramentas eletrônicas. Nas palavras do próprio autor:

Há um debate na definição do status da área: a Linguística de Corpus é disciplina ou metodologia? Claramente, a Linguística de Corpus não é uma disciplina tal qual psicolinguística, sociolinguística ou semântica, pois seu objeto de pesquisa não é delimitado como em outras áreas. A Linguística de Corpus não se dedica a um assunto definido (...). Ao contrário, ocupa-se de vários fenômenos comumente enfocados em outras áreas (léxico, sintaxe, textura). É então uma metodologia da qual outras áreas podem se fazer valer? A princípio, sim. (...)

Se a Linguística de Corpus é metodologia ou não, depende da definição de metodologia que está sendo usada. Entendendo metodologia como instrumental, então é possível aplicar o instrumental da Linguística de Corpus livremente e manter a orientação teórica da disciplina original. (BERBER SARDINHA, 2004, p. 35-36)

Uma clara contribuição dessa chamada "metodologia" para a Linguística é o fato de o pesquisador lidar com dados reais da linguagem, e não chegar a conclusões baseadas em exemplos construídos artificialmente, ainda que correspondendo à intuição dos falantes. E mais: com esse procedimento, o número de informações com que o linguista é capaz de lidar é inúmeras vezes maior, alcançando enorme fidedignidade entre as conclusões alcançadas em relação a um corpus e as conclusões que podem ser imputadas à língua como um todo. Enfim, quase todos os estudos quer da linha diacrônica, quer da sincrônica encontram na Linguística de Corpus um suporte jamais alcançado na história da pesquisa em linguagem.

Como os demais temas de pesquisa, os estudos sobre a metáfora também voltam os olhares para as técnicas e métodos proporcionados pela Linguística de Corpus, especialmente quando se pretende investigar as ocorrências dessa modalidade de linguagem no cotidiano dos usuários da língua. Berber Sardinha $(2009$, p. 1) destaca, na introdução de um texto ainda não publicado, que 
Tem existido um crescente interesse na utilização de corpora na pesquisa sobre metáfora nos últimos anos, e como resultado disso um certo número de ferramentas e técnicas tem sido proposto e utilizado para identificação de metáforas. No entanto, muito pouco se sabe a respeito de suas habilidades para recuperar todas e somente metáforas a partir dos corpora. ${ }^{8}$

Apesar dessa dificuldade, é inegável a contribuição que modernas tecnologias vêm dando à ciência no âmbito do estudo da metáfora. Questões jamais imaginadas até então passam a ser investigadas, como: qual a relação entre a metáfora e o processamento cognitivo humano? Quais são os limites entre o sentido literal e não literal na linguagem? Em que situações os falantes fazem uso de construções metafóricas em vez das correspondentes construções não metafóricas? Qual o grau de ocorrência de construções metafóricas numa dada língua?

Muita contribuição no sentido de possíveis respostas a esses questionamentos vem sendo dada por dois grandes estudiosos do assunto: Anatol Stefanowitsch e Stefan Gries. Stefanowitsch (2005), por exemplo, realiza um estudo de extrema relevância com vistas a explicar se o uso da linguagem metafórica é motivado por questões estilísticas ou por princípios cognitivos. O autor desenvolve essa questão analisando as ocorrências de algumas expressões metafóricas da língua inglesa, comparando as situações de uso das mesmas em contraposição à situação de uso das respectivas expressões não metafóricas.

Nesse artigo, o autor defende a hipótese cognitiva sobre a metáfora, segundo a qual ela é um elemento sistemático e pervasivo na linguagem cotidiana, um fenômeno conceitual/mental que nos possibilita a compreensão de uma ideia (mais abstrata) em termos de outra ideia (mais concreta), em oposição à hipótese estilística, cujos adeptos defendem que a metáfora é um recurso extraordinário de linguagem, uma figura de linguagem empregada para obter efeitos estéticos, largamente empregada na literatura, retórica e outros registros que utilizam a linguagem como "ornamento" das ideias (STEFANOWITSCH, 2005, p. 163). Como argumentos em favor da hipótese cognitiva, são apresentados os seguintes:

i) se a metáfora fosse um fenômeno estilístico simples, ela não apresentaria tão alto grau de sistematicidade e ocorrência;

\footnotetext{
${ }^{8}$ No original: "There has been growing interest in using corpora in metaphor research in recent years, and as a result a number of tools and techniques have been proposed and used for metaphor identification. However, very little is known about their ability to retrieve all and only metaphors from corpora."
} 
ii) se a metáfora fosse um recurso ornamental da linguagem, existiria sempre uma expressão literal correspondente a cada expressão metafórica;

iii) nas metáforas, o mapeamento é sempre unidirecional, acontecendo do domínio mais concreto para o mais abstrato, e não vice-versa. Se a metáfora fosse um recurso puramente estilístico, a unidirecionalidade seria acidental, e não sistemática.

A ideia central sobre a linguagem metafórica na hipótese cognitiva é que o seu uso pode reduzir dificuldades de processamento do sentido. Assim, a metáfora pode ser descrita como um elemento que oferece "suporte conceitual" para a nossa apreensão de conceitos complexos. Daí o fato de concebermos os conceitos mais abstratos dentro de um domínio mais concreto. ${ }^{9}$

Estudos desse porte desmistificam a ideia de que o modo básico de utilização da linguagem humana é o uso do sentido literal e que o sentido metafórico é um mero correspondente opcional daquele. Tais estudos vêm demonstrando que a linguagem metafórica - e, por extensão, o raciocínio metafórico - é um elemento essencial da cognição humana. Gibbs Jr. (2002) já expusera em seu artigo que não faz sentido simplesmente contrapor o sentido literal ao sentido não literal, uma vez que não existe uma linha divisória entre essas duas formas de processamento do sentido, além de que não existe uma única forma de sentido literal nem tampouco uma única forma de sentido não literal. No bojo deste, existem, por exemplo, o sentido metafórico, o idiomático, o irônico, o metonímico etc. No processamento de uma sentença não literal, diferentes tipos de sentido são ativados em diferentes pontos da sentença.

Stefanowitsch utiliza, em várias de suas pesquisas, um procedimento bastante comum na Linguística de Corpus, que é a análise dos colocados, isto é, as palavras que ocorrem com frequência considerável na vizinhança de alguns nódulos (palavras e expressões) escolhidos para análise. Com esse procedimento, numa extensão da análise colocacional, Stefanowitsch e Gries desenvolveram um método através do qual é investigada a interação de lexemas e as estruturas gramaticais a eles associadas, com aplicação no estudo de expressões linguísticas

\footnotetext{
${ }^{9}$ Um bom exemplo disso é o fato de conceitualizarmos o tempo (abstrato) em termos de dinheiro (concreto), no emprego de várias expressões verbais: gastar tempo, ganhar tempo, economizar tempo, perder tempo, ceder tempo, tomar tempo etc. O contrário não ocorre, ou seja, não conceitualizamos dinheiro em termos de tempo, medindo-o em segundos, minutos, horas etc.
} 
de vários níveis (palavras, expressões fixas, estruturas de argumento etc.). A esse procedimento os autores chamam de análise colostrucional (collostructional analysis) ${ }^{10}$.

Stefanowitsch e Gries (2003, p. 210) afirmam que "recentemente (...) o foco dentro da linguística de corpus mudou para uma visão mais holística da língua" ${ }^{11}$, chamando a atenção para o fato de que gramática e léxico não são elementos fundamentalmente diferentes, da maneira como essa antiga dicotomia tem sido vista nos estudos da linguagem, existindo muitas expressões ignoradas ao longo dos tempos que servem de importantes elos entre esses dois polos. Trata-se de um estudo que toma por base preceitos da chamada Gramática de Construções, aplicando-se de forma muito pertinente ao estudo de collocations, chunks ${ }^{12} \mathrm{e}$ outras expressões linguísticas. Não se trata especificamente de uma metodologia para estudo da metáfora, mas como a língua é plena de expressões metafóricas entrincheiradas ${ }^{13}$, esse tipo de estudo também nos é de grande valia.

\section{Descrição e análise linguística do corpus}

\subsection{Descrição do banco de textos}

Procederemos à análise de textos escritos em língua portuguesa, extraídos do corpus organizado para esse fim, de forma que os resultados alcançados possam mostrar-se aplicáveis a uma ampla variedade de textos dentro da língua.

Para a composição do nosso corpus de análise, optou-se pelo gênero textual redação de vestibular. Trata-se de um tipo de produção textual muito difundido no meio escolar, cujo propósito é autorrecursivo, ou seja, o objetivo principal é treinar ou demonstrar habilidades de comunicação escrita dentro da norma padrão da língua. As redações de vestibular, sejam do estilo tradicional (realizado ao final do Ensino Médio) ou seriado (realizado ao longo dos anos que compõem o Ensino Médio), são produzidas num contexto específico de avaliação de desempenho de escrita e concatenação de ideias em torno de um tema. Elas não atendem a um propósito comunicativo externo à instituição de ensino e correspondem a um tipo de produção

\footnotetext{
${ }^{10}$ Cf. Stefanowitsch e Gries (2003).

${ }^{11}$ No original: "recently (...) the focus within corpus linguistics has shifted to a more holistic view of language".

12 Mantivemos aqui os originais em inglês por não existirem adequadas traduções para esses termos em português.

$13 \mathrm{O}$ entrincheiramento (do inglês entrenchment) corresponde ao fenômeno normalmente associado à cristalização com que certas palavras e expressões são utilizadas no sistema linguístico, como que se apresentando na forma de blocos imutáveis, diferentemente do uso de palavras livres nos enunciados sujeitas a modificações tanto no que diz respeito à forma quanto ao significado.
} 
induzida, não espontânea. Essas características, no entanto, não invalidam estudos sobre esse tipo de produção. Nas palavras de Bezerra (2008, p. 138),

\begin{abstract}
Embora defendamos a utilização de situações efetivas de escrita em sala de aula, não estamos eliminando o fato de que o texto, ao chegar aí, perde parte da carga comunicativa que tem, já que se torna objeto de ensino/aprendizagem. Com isso, observamos que o trabalho com a redação (entendida como um texto inerte), com a produção textual (concebida como um texto produzido em uma situação comunicativa) e com o gênero textual (entendido como um enunciado produzido em uma situação comunicativa específica, de acordo com um tema, uma composição e um registro linguístico) tem um ponto comum, que é ser objeto de ensino. Por isso, não se deve desfazer-se dessa característica (...) sob o pretexto de que o importante é respeitar as práticas sociais da escrita e seus usos.
\end{abstract}

Em outras palavras, ressalvado o fato de que redações escolares - e aí incluímos as redações de vestibular - não atendem a um propósito comunicativo espontâneo, trata-se de um tipo textual muito difundido na prática escolar, capaz de revelar muitos fatos no âmbito do raciocínio com a linguagem.

O nosso corpus foi composto por um total de 500 (quinhentas) redações produzidas entre os anos de 2005 e 2007 em diferentes processos seletivos para ingresso no ensino superior da Universidade Presidente Antônio Carlos, instituição multicampi da rede particular cuja sede se localiza na cidade de Barbacena (MG) e que possui unidades de ensino em várias outras cidades, incluindo uma unidade no estado de Tocantins (Instituto Tocantinense Presidente Antônio Carlos).

A escolha desses textos foi aleatória. Esse procedimento faz parte do método estatístico da pesquisa científica, aplicando-se a seleção de amostragem casual simples, em que todos os conjuntos de textos disponíveis tinham igual probabilidade de serem escolhidos. Com isso, pretendemos detectar construções de uso metafórico no corpus e sobre elas realizar nossa análise qualitativa, de forma que tais construções tenham a probabilidade de serem representativas de todo o montante de textos à nossa disposição.

A proposta de analisar textos escritos autênticos justifica-se pelo objetivo de lidar com elementos da língua em uso real e efetivo (ainda que a produção dos textos seja induzida, conforme comentamos), e não criados para satisfazer a alguma hipótese de pesquisa. $\mathrm{Na}$ composição do corpus, mantivemos a escrita original dos textos, a fim de evitar qualquer tipo 
de interferência que pudesse prejudicar os nossos resultados, ferindo a autenticidade dos mesmos. $^{14}$

Para se ter uma noção da dimensão do nosso corpus, ele possui um total de 84.450 palavras, conforme se pode levantar através do listador de palavras do WordSmith Tools ${ }^{\circledR}$, programa muito utilizado como suporte para vários tipos de análises linguísticas. Desse total de ocorrências (tokens), são identificadas 8.734 palavras diferentes, ou tipos (types). Vejam-se os dados na figura abaixo, em que está destacado o total de palavras ocorrentes no corpus:

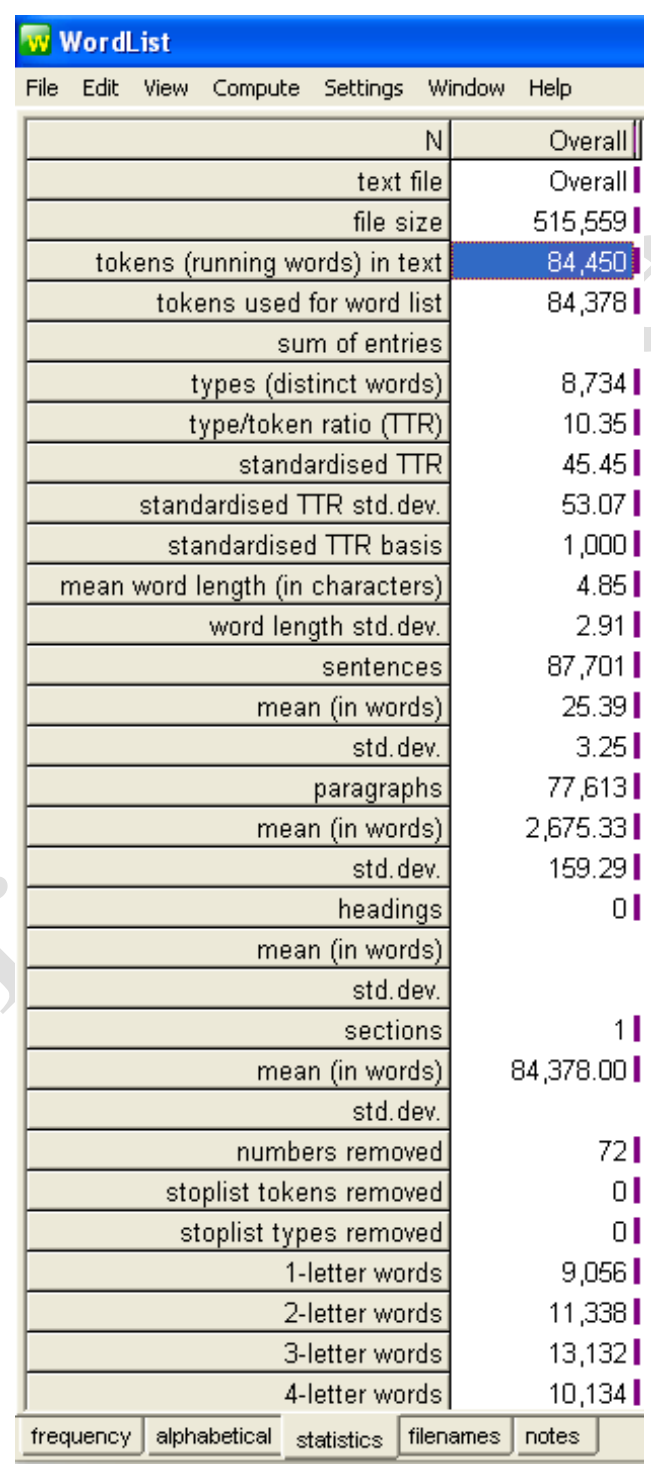

Figura 4 - Descrição geral do corpus pelo listador de palavras do WordSmith Tools ${ }^{\odot}$

${ }^{14}$ A escolha dos textos para a composição do corpus foi anterior ao trabalho de correção que a equipe do processo seletivo realiza para a classificação dos candidatos. Foram incluídas, assim, redações de níveis muito diferenciados, de candidatos que tanto foram aprovados quanto reprovados nos concursos. Portanto, a nota obtida pelos candidatos nas redações em nenhum momento influenciou a nossa escolha. 
De acordo com Berber Sardinha (2004, p. 26), um corpus dessa natureza é classificado como pequeno-médio, em classificação baseada na observação dos corpora normalmente utilizados em pesquisas (um corpus pequeno-médio, segundo o autor, possui de 80.000 a 250.000 palavras).

Na montagem desse banco de textos, eles foram numerados de 001 a 500 . A tabela a seguir apresenta uma descrição geral dos subconjuntos de redações que compõem o corpus, compreendendo a quantidade produzida em cada local, as cidades em que as mesmas foram produzidas e o tema que serviu de motivação para a produção de cada subconjunto:

Tabela 1 - Dados gerais dos textos do corpus, separados por grupos

\begin{tabular}{|c|c|c|l|}
\hline REDAÇÕES & QUANTIDADE & LOCAL & \multicolumn{1}{|c|}{ TEMA (RESUMIDO) } \\
\hline 001 a 181 & 181 & Araguaína (TO) & Crimes virtuais \\
\hline 182 a 229 & 48 & Araguaína (TO) & A pirataria no Brasil \\
\hline 230 a 246 & 17 & Medina (MG) & A felicidade \\
\hline 247 a 256 & 10 & Teófilo Otoni (MG) & Sonhos de simplicidade \\
\hline 257 a 466 & 210 & Araguaína (TO) & A internet \\
\hline 467 a 500 & 34 & Barbacena (MG) & A destruição da natureza \\
\hline
\end{tabular}

\subsection{Procedimentos de tratamento dos textos}

Como se trata da composição de um corpus de pesquisa que futuramente pode servir também a outros tipos de investigação, e com o intuito de não incorrermos em falhas metodológicas, seguimos os procedimentos gerais para tratamento do corpus, que normalmente integram esse tipo de abordagem, a saber:

i) Uma vez que as redações são manuscritas, após selecionadas elas foram transcritas ao computador utilizando-se o programa Microsoft Word for Windows ${ }^{\circledR}$, em espaço simples, fonte Times New Roman tamanho 12, alinhamento de margem à esquerda. Seguimos um procedimento corriqueiro desse tipo de montagem de corpus: deixar um espaço em branco entre os parágrafos, apesar de não interessar diretamente para a nossa pesquisa a identificação de tais. Entre o título da redação - quando existente - e o primeiro parágrafo, deixaram-se dois espaços em branco para a identificação daquele.

ii) Após organizados em pastas no computador, os textos foram salvos também como "texto sem formatação" (com a extensão .txt), procedimento fundamental para que a aplicação de ferramentas eletrônicas como o WordSmith Tools $^{\circledR}$ não seja prejudicada com a identificação de caracteres estranhos ao programa. 
iii) A partir daí, levantamos as informações gerais sobre o corpus, a exemplo dos dados da Figura 4, para se ter uma noção geral do ambiente de pesquisa com que estamos lidando. $\mathrm{O}$ software utilizado serviu como ponto de partida para a identificação das características gerais do banco de textos e também para realizar buscas de palavras e expressões no corpus à medida que fomos realizando leituras e análises de cunho qualitativo.

As buscas de palavras e expressões no corpus com o apoio de recurso eletrônico são de fundamental importância num trabalho desse porte, uma vez que proporcionam levantamentos que seriam impossíveis de serem feitos somente através da chamada leitura manual. O grau de precisão dessas buscas é altíssimo, além da capacidade de obtenção de dados importantes para a análise em tempo imediato.

\subsection{O uso da ferramenta eletrônica para análise}

A ferramenta eletrônica escolhida para análise do nosso corpus, o WordSmith Tools ${ }^{\circledR}$, possui três componentes básicos: o concordanciador (Concord), o listador de palavras (WordList) e o listador de palavras-chave (KeyWords).

O recurso do concordanciador permite que o analista visualize os "colocados", que são os itens lexicais que ocorrem com um nódulo de uma busca. Essa busca pode ser realizada com alcances diferenciados, chamados de "janelas" ou "horizontes", que consiste em quantidades de palavras à esquerda e à direita escolhidas pelo pesquisador. O concordanciador também fornece a "frequência", que é o número de ocorrências tanto do nódulo quanto de seus colocados.

Através do listador de palavras, outro recurso da ferramenta eletrônica, é possível obter informações do corpus analisado em três segmentos diferentes: um relativo às informações gerais do banco de textos (número de palavras, tipos e ocorrências; número de parágrafos; razão entre tipos e ocorrências; extensão média das palavras e dos parágrafos etc.); outro relativo à frequência de ocorrência de cada palavra do corpus, medida em porcentagem em relação às demais palavras do texto, da mais frequente até a menos frequente do corpus; e o último relativo à listagem de todas as palavras do corpus em ordem alfabética, acompanhadas da frequência em que ocorrem.

Por fim, o listador de palavras-chave estabelece uma comparação entre as palavras de um texto ou conjunto de textos selecionados em relação a um corpus que serve como referência. No caso de nossa pesquisa, não utilizamos esse recurso. 


\subsection{Análise do corpus}

O grande desafio para os estudos sobre metáfora baseados em corpora é a identificação de nódulos que podem ser considerados metafóricos, já que os mapeamentos entre domínios cognitivos não estão ligados a formas linguísticas específicas. Na tentativa de dar um rumo à nossa análise tendo em vista essa dificuldade, buscamos suporte em Stefanowitsch (2006). O autor apresenta algumas estratégias para contornar esse problema, que se resumem no seguinte ${ }^{15}$ :

i) Busca manual - Muitos estudos se baseiam na coleta manual das ocorrências de construções metafóricas, o que limita muito o trabalho do pesquisador, evidentemente, no caso de trabalhos baseados em corpora extensos.

ii) Busca por vocabulário de domínio-fonte - Algumas expressões metafóricas baseiam-se em itens lexicais específicos do domínio-fonte. Constitui, portanto, uma estratégia de pesquisa realizar a busca começando por elementos do léxico ou conjuntos de elementos que são potencialmente formadores de metáforas.

iii) Busca por vocabulário de domínio-alvo - Muitos estudos sobre a metáfora são realizados tendo-se em vista domínios-alvo específicos, bem como os mapeamentos conceituais que os estruturam; assim, esse tipo de busca pode ser bastante producente. Existem algumas restrições quanto a esse aspecto, especialmente o fato de que esse método se aplica muito bem quando se trata de um corpus muito representativo de textos que lidem com um domínio-alvo específico, além de funcionar bem, obviamente, quando se trata de construções cujo domíniofonte apresente uma associação sistemática e previsível com o domínio-alvo em questão.

iv) Busca por sentenças que contenham itens lexicais tanto do domínio-fonte quanto do domínio-alvo - Os dois tipos de busca apresentados anteriormente podem combinar-se no mesmo processo. E, assim como os dois procedimentos anteriores não são completos, este também pode apresentar problemas. Trata-se de um processo que funciona muito bem em se tratando de expressões cujo mapeamento conceitual é conhecido de antemão - ou, para utilizar uma expressão do próprio Stefanowitsch, no caso de "padrões metafóricos" (metaphorical patterns).

\footnotetext{
${ }^{15}$ Cf. Stefanowitsch (2006, p. 2-6). O autor confere especial importância às três primeiras estratégias apresentadas.
} 
v) Busca de metáforas baseada nos "marcadores de metáfora" (markers of metaphors) Existe um certo número de expressões na língua, muitas vezes de natureza metalinguística, que sinalizam explicitamente a presença de metáforas, tais como "metaforicamente falando", "figurativamente falando", "literalmente" etc., bem como o recurso gráfico das aspas.

vi) Extração a partir de um corpus etiquetado por campos/domínios semânticos - A primeira estratégia descrita acima pode ser estendida da seguinte forma: pode-se especificar um domínio-fonte e operar a busca por todos os itens lexicais pertencentes a esse domínio, em vez de trabalhar com conjuntos de lexemas, que ficam sempre incompletos. Stefanowitsch qualifica esse método como bastante promissor.

vii) Extração a partir de um corpus etiquetado por mapeamentos conceituais - Esse tipo de busca seria grandemente valioso para os estudos da metáfora, mas o grande problema em relação a ele é justamente realizar as marcações que discriminem os mapeamentos conceituais.

A etiquetagem é muito produtiva em análises textuais, mas, no caso de pesquisas envolvendo metáforas, ainda se constitui um procedimento muito complexo. A identificação de metáforas realizada por recursos eletrônicos é feita, atualmente, em termos de probabilidade de emprego metafórico de uma determinada expressão com base na comparação com a co-ocorrência desse mesmo nódulo em outros corpora pré-analisados ${ }^{16}$.

Levando-se em consideração todos os aspectos levantados, e tendo em vista o foco da nossa pesquisa voltado para uma análise qualitativa envolvendo metáforas e organização textual, diante dos recursos colocados à disposição para a pesquisa e que nos levem a um grau de total confiabilidade em relação aos resultados alcançados, estabelecemos os seguintes procedimentos metodológicos para análise dos textos:

i) Busca manual de metáforas mais relevantes em textos escolhidos aleatoriamente nos seis subgrupos de redações apresentados na Tabela 1, de maneira a contemplar uma análise preliminar em textos elaborados sob diferentes propostas de tema. Como os subgrupos de redações variam muito entre si, em relação ao número de textos que os compõem,

\footnotetext{
${ }^{16}$ São muito raros os programas de identificação de metáforas, sendo o único disponível na Internet à época desta pesquisa o do CEPRIL - Centro de Pesquisa, Recursos e Informação em Linguagem, da PUC-SP (disponível em: http://www.corpuslg.org/tools/), que realiza buscas em língua portuguesa e língua inglesa. Esse identificador funciona como um etiquetador, apresentando, para cada palavra do corpus a que o usuário pode submeter, uma informação correspondente à probabilidade de ela ser metafórica. Essa probabilidade varia de $0,01 \%$ (zero vírgula zero um por cento, ou seja, praticamente nenhuma probabilidade) a 100\% (cem por cento, isto é, certeza de uso metafórico), que o programa oferece através da indicação "Avg.Prob”.
} 
estabelecemos a proporção de escolha de um texto para cada conjunto de no máximo setenta redações dentro de cada tema. Assim, foram selecionados: 3 textos no subgrupo I; 1 texto no subgrupo II; 1 texto no subgrupo III; 1 texto no subgrupo IV; 3 textos no subgrupo V; e 1 texto no subgrupo VI. Totalizam, assim $10(\mathrm{dez})$ textos para esse procedimento inicial.

ii) Identificação de possíveis vocabulários de domínio-fonte e domínio-alvo a partir da busca manual nos dez textos mencionados acima. Embora esse procedimento não garanta o alcance de grande número de ocorrências metafóricas no corpus como um todo, pode constituir-se um ponto de partida para buscas mais minuciosas em etapas posteriores.

iii) Levantamento de construções metafóricas em outros textos do corpus, além dos dez textos iniciais, num processo que mescla a busca manual e a busca realizada através da ferramenta eletrônica com base nos possíveis vocabulários de domínio-fonte e domínio-alvo mencionados acima.

iv) Análise qualitativa de variados textos do corpus, de acordo com a relevância dos levantamentos feitos até então, com vistas ao comportamento da metáfora dentro desses textos.

\subsubsection{Conclusões preliminares da busca manual}

Procedendo-se ao levantamento inicial dos padrões metafóricos nas redações selecionadas em cada subgrupo do nosso corpus de análise, observa-se a recorrência de alguns esquemas metafóricos já salientados por vários estudiosos da Linguística Cognitiva como padrões de processamento mental existentes na espécie humana. $\mathrm{O}$ reconhecimento desses padrões se dá não só pelo grande número de ocorrências nos textos analisados, como também pela sistematicidade com que ocorrem. Isso nos leva a acreditar na existência de um modo de processamento de sentidos, no âmbito da cognição humana, que segue uma certa tendência na conceitualização de ideias.

A tendência identificada na nossa amostragem resume-se no seguinte:

i) elementos de natureza diversa, quer concretos, quer abstratos, são concebidos como lugares, espaços onde acontece alguma coisa;

ii) elementos abstratos - que, portanto, dizem respeito a ações e sentimentos - são concebidos como elementos concretos, que possuem uma corporeidade física;

iii) elementos inanimados, quer concretos, quer abstratos, são concebidos em termos de seres animados, que possuem vida própria, que praticam ações. 
Outros esquemas metafóricos foram encontrados no corpus, mas esses três têm uma presença tão marcante nos textos a ponto de todo o conteúdo girar em torno deles. Não se trata de ocorrências isoladas; muitas vezes, são até interpenetrantes, ou seja, seres inanimados podem ser metaforizados como seres animados que ao mesmo tempo praticam ações em espaços também metafóricos.

A essas alturas, cremos já ter ficado bastante claro que a metáfora não é mero recurso estilístico, sendo um elemento intrínseco do modo de raciocinar humano. Dando continuidade a esse ponto de vista, através do levantamento que ora fizemos no nosso corpus, mais do que corroborar esse pensamento, fica visível que a metáfora participa sistematicamente da organização do texto como um todo, estabelecendo parâmetros de inserção de conteúdos no mesmo.

Porém, a metáfora não atua sozinha nessa função. Na verdade, informações de ordem metafórica e não metafórica se juntam no decorrer do texto e atuam concomitantemente na apresentação dos conteúdos. Ações são praticadas em espaços tanto metafóricos quanto não metafóricos, os elementos que possuem corporeidade física são apresentados no texto também de forma metafórica ou não metafórica, e assim por diante. Não se quer exaltar a importância do processo de metaforização em detrimento de outros recursos de organização textual, assaz importantes para a manutenção da coesão e da coerência textuais, mas fica claro que, sem as metáforas, esse quadro não seria instaurado - ou seria de forma incompleta, só no âmbito não metafórico.

Uma importante conclusão que vai nortear todo o rumo desta pesquisa é a seguinte: manifesta-se nítida a ideia de que a metáfora se situa num domínio cognitivo da organização textual capaz de nos fazer vislumbrar esses textos escritos à maneira de narrativas típicas, já que afloram, na tessitura do texto, os seguintes elementos:

i) espaço ou lugar, apresentado de maneira geral no texto, onde ocorrem todas as ações descritas, ou de forma localizada, existindo pequenos espaços para um grupo circunscrito de ações;

ii) personagens, elementos metaforizados ou não, que atuam ao longo do texto. A existência deles é vital para a compreensão dos textos como narrativas;

iii) tempo, informação nem sempre explícita nas redações, frequentemente não metafórica. Muitas vezes ele se manifesta na sequenciação das ações, sendo um importante recurso da coerência textual; 
iv) ações, apresentadas explicitamente nos textos em relação a personagens metafóricos ou não, através de formas verbais que também podem ser metafóricas.

Dentro da tipologia textual clássica, raríssimos textos ou passagens de textos do nosso banco de redações poderiam ser categorizados como essencialmente narrativos, que normalmente são marcados com a existência dos elementos listados acima na própria superfície textual. Em outras palavras, para que um texto seja considerado narrativo, é necessário que apresente explicitamente os elementos espaço, personagem, tempo e ação, ou pelo menos a maioria deles, na nossa tradição de gêneros textuais. No caso do objetivo da produção de redações em processos seletivos, essa estrutura é até desaconselhável, uma vez que o comando para a elaboração dos textos direciona para a produção de ideias ou apresentação do ponto de vista dos candidatos sobre um determinado tema, ou seja, recai-se no esquema tradicional das dissertações, e não das narrações.

$\mathrm{Na}$ tentativa de esclarecer melhor essas questões e aprofundar um pouco mais o estudo da relação entre narração e metáfora, propomos, com base nos postulados da Gramática Cognitiva, a existência de um domínio no qual todas as informações narrativas são processadas, isto é, no qual convergem elementos como espaço, personagem, tempo e ação, cujo reflexo se manifesta no texto escrito. A esse domínio, que corresponde ao espaço da mescla no modelo de Fauconnier e Turner, estamos denominando Domínio Cognitivo da Narrativa, o qual descreveremos com mais detalhes a seguir.

\subsubsection{O modelo dos Domínios Cognitivos da Narrativa}

O Domínio Cognitivo da Narrativa (doravante DCN) é, pois, um espaço cognitivo no qual vislumbramos a conjugação de elementos metafóricos e não metafóricos na realização das ações e na apresentação do conteúdo narrativo. Os limites do DCN coincidem basicamente com os limites do texto, entendido este em sua acepção mais ampla, além da mera sequência de elementos da superfície (palavras, frases, parágrafos etc.), atingindo os fatores cognitivos envolvidos na sua organização. Esse domínio engloba, claro, informações de ordem pragmática, cultural, contextual etc., envolvidas no processo de composição textual.

O espaço da mescla é insuficiente para abarcar todas essas informações. Ele explica muito bem a ocorrência de metáforas e outros fenômenos, mas muitas informações contidas num texto estão fora da mescla, incluindo informações não metafóricas. O espaço da mescla é o espaço da compressão, e o texto não é só compressão. Em virtude disso, propomos situar o 
DCN de forma a englobar o espaço-mescla e, ao mesmo tempo, abrigar as informações não metafóricas do texto e quaisquer outras informações que sejam pertinentes para a compreensão do mesmo em termos narrativos.

Assim, chegamos ao seguinte modelo de apresentação do DCN em relação ao modelo da mesclagem conceitual:

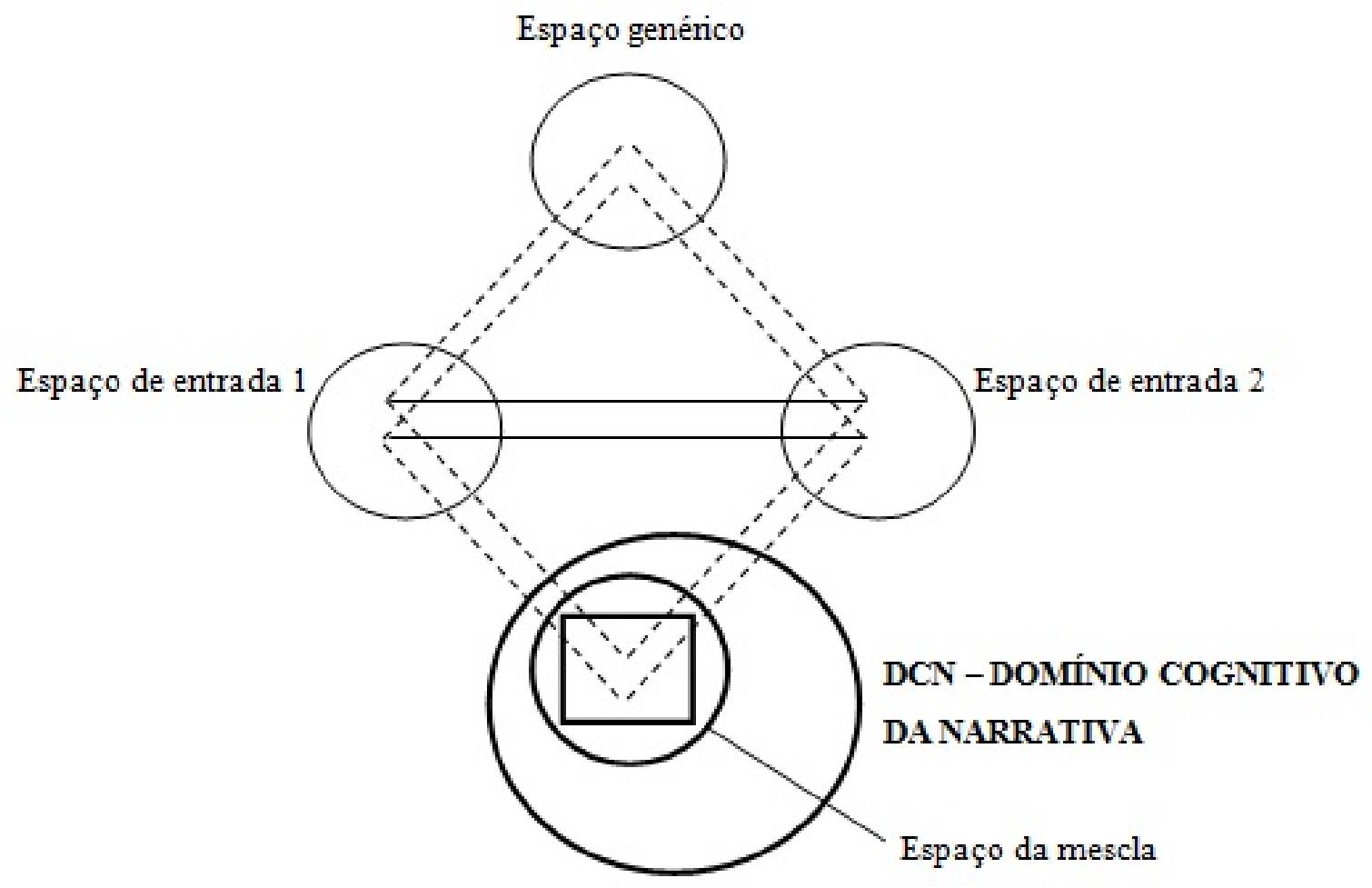

Figura 5 - Estrutura do DCN em relação ao modelo da mesclagem conceitual

Vejamos um exemplo de representação de um texto do nosso corpus de pesquisa nos parâmetros de representação do modelo aqui proposto, a saber, a redação de $n^{\circ} 187$, que segue transcrita abaixo:

(2) Pirataria, uma necessidade.

Como se sobressair dos problemas que atingem hoje a maioria da sociedade brasileira? A miséria está presente em muitas famílias no nosso país, e isso faz com que elas procurem vários tipos de emprego, instantâneos, para que possam ir sobrevivendo. Devido à grande carência do povo brasileiro, a pirataria tornou-se um negócio tão lucrativo, e o único para alguns.

É notável a situação em que vive a maioria do povo brasileiro, salários baixos, endividados devido ao grande consumo, e sem mão de obra qualificada. Tudo isso deixa a própria sociedade numa "saia justa", e para não entrarem no mundo da 
criminalidade, as pessoas vêem como solução trabalhar com produtos pirateados. A pirataria é ilegal sim, porém, para alguns é a única base de sobrevivência.

No Brasil a pirataria tornou-se muito comum, e por ser um comércio que tanto cresceu beneficiando os mais pobres, e por ser também de baixo custo, causou abalo no mercado dos produtos originais, que por possuírem um alto custo para compra não são viáveis à comunidade mais pobre.

É certo que em todo o mundo a pirataria é ilegal, um crime. Porém, dentro dos padrões de criminalidade do Brasil, esse é um crime suave, e por uma boa causa. Comparado com outros crimes atuais, a pirataria deve ser classificada como um bem, pois está dando comida e dignidade às famílias brasileiras que necessitam de apoio.

No texto acima, podemos apontar os seguintes elementos componentes da narrativa:

- Tempo (não metafórico): hoje.

- Personagens não metafóricos: a maioria da sociedade brasileira; o povo brasileiro; famílias brasileiras.

- Personagens metafóricos: miséria (ela está presente no espaço metafórico "muitas famílias"); famílias (elas procuram vários tipos de emprego para sua sobrevivência); a sociedade (fica numa "saia justa"); pirataria (está dando comida e dignidade às famílias brasileiras).

- Espaços não metafóricos: no nosso país; Brasil; todo o mundo.

- Espaços metafóricos: muitas famílias (local onde se encontra a "miséria"); mundo da criminalidade (onde as pessoas tentam não entrar); mercado dos produtos originais (sofreu abalo causado pela pirataria); saia justa (onde fica a sociedade).

$\mathrm{Na}$ redação de número 187 transcrita acima, da mesma maneira como acontece em outros textos, o tempo é marcado não metaforicamente, através do introdutor de espaço "hoje". Em relação a esse tempo, personagens e espaços são apresentados, no âmbito da metáfora e da não metáfora, conforme a listagem apresentada acima.

Em relação aos espaços metafóricos estabelecidos no texto, percebe-se que eles se ligam exclusivamente a alguns personagens, não funcionando como locais de ação de vários deles. Por isso, uma representação mais detalhada no modelo do DCN é capaz de representar melhor essa situação.

Os personagens e os espaços não metafóricos aparecem, em alguma proporção, repetidas vezes, através de expressões linguísticas bem similares, podendo ser resumidos no seguinte:

- Personagens não metafóricos: brasileiros. 
- Espaços não metafóricos: Brasil; mundo.

Já em relação aos personagens e espaços metafóricos, nota-se uma variedade muito maior, não sendo possível resumi-los, como fizemos com os não metafóricos.

Diante desse quadro, podemos traçar a seguinte representação do DCN do texto transcrito em (2):

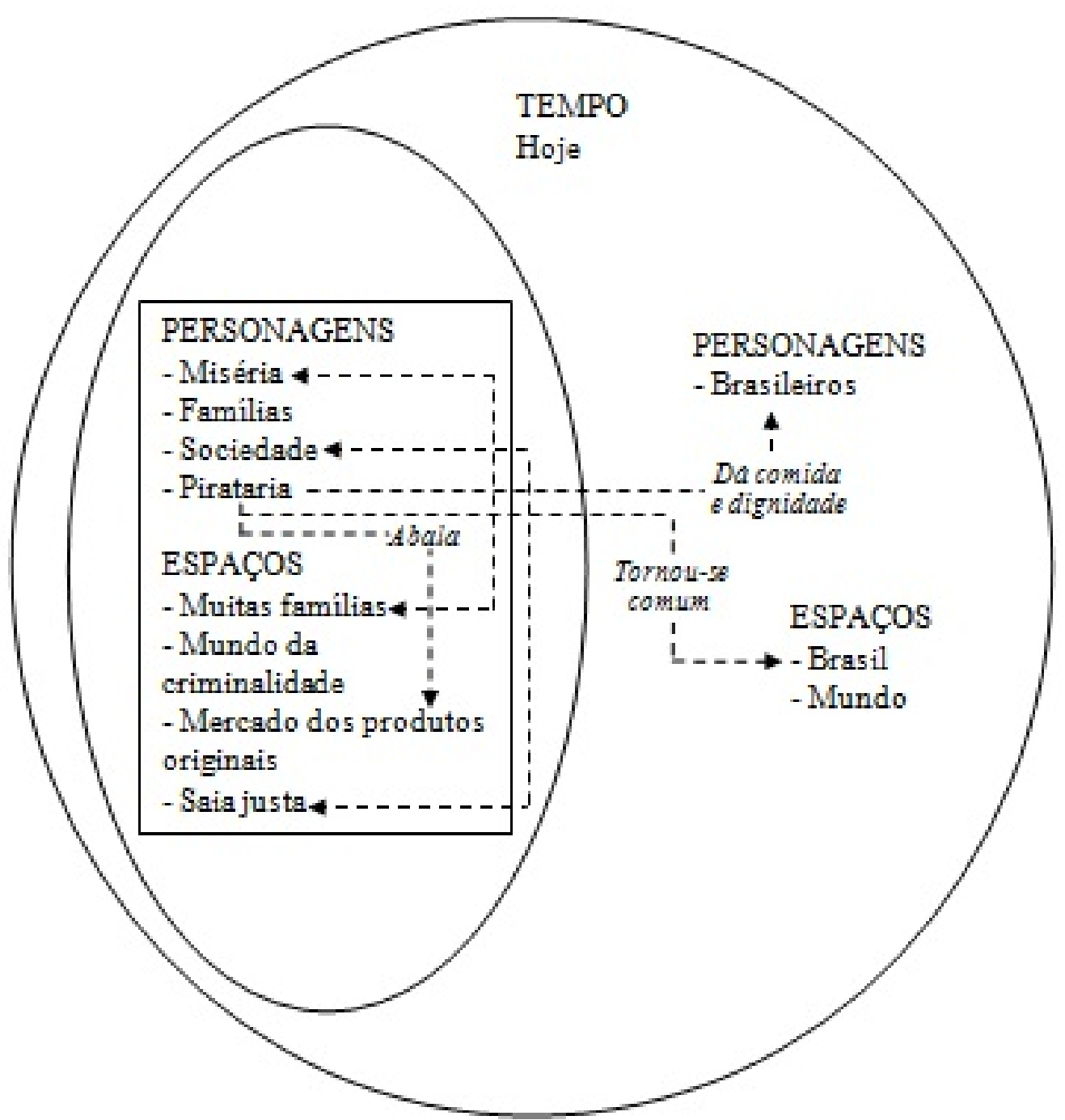

Figura 6 - Representação detalhada do DCN da redação nº 187

Nem todas as relações de sentido estão representadas na figura acima; portanto, a narrativa não se esgota com as relações que foram apresentadas. Essa é uma maneira de exemplificarmos como se dão tais relações, envolvendo diferentes elementos metafóricos e não metafóricos, para a constituição narrativa do texto no âmbito de sua representação semântico-cognitiva. 


\section{Considerações finais}

Considerar que, no processo de produção de textos, a mente humana apresenta o funcionamento próprio da estruturação narrativa é, em outras palavras, apresentar a narração como o principal procedimento linguístico-textual, o princípio organizador das ideias, mesmo que, na estrutura superficial, o texto resulte numa não narrativa de acordo com a clássica tipologia textual.

O que se mostra como novidade no contexto da nossa pesquisa é a forma como esse processo se desenvolve, envolvendo metáfora (que se situa no espaço da mesclagem conceitual) e não metáfora.

A partir dessa constatação, o esquema dos DCNs pode ser incorporado pela Linguística Textual, que é a área por excelência que deu impulso às descobertas dos aspectos de coesão e coerência textuais aplicados a textos de natureza diversa; pode ser aproveitado também para os diversos tipos de estudo realizados no bojo da Semântica, área que trata dos processos de produção do sentido e sua correlação com aspectos que vão além do texto, interagindo com a Pragmática; o modelo se constitui também como um bom subsídio para os estudos empreendidos nas diversas vertentes da Análise do Discurso, uma vez que as informações sobre tempo, espaço e personagens são claramente relacionadas a fatores de ordem pragmática, histórica e linguística a que essa área comumente recorre; e, apesar de apresentar embasamentos teóricos e formas de abordagem diferentes das teorias linguísticas, o modelo também pode ser utilizado em estudos literários, uma vez que seja feita a necessária equalização dos conceitos de metáfora e narrativa. Mais do que uma contribuição teórica para a Literatura, pensa-se na possibilidade de aproveitamento do modelo de análise para esclarecer aspectos que não são exclusivos da teoria linguística.

Sendo mais específico em nossa abordagem, o trabalho apresenta também ampla abertura para a aplicabilidade de ferramentas eletrônicas da Linguística de Corpus, não só empreendendo pesquisas em direção ao grau de eficácia das mesmas quando o tema é a metáfora, mas contribuindo para mostrar também o nível de dificuldade e o alcance de procedimentos quando do seu uso efetivo. Na tese que deu origem a este artigo, não desenvolvemos um aparato dentro dessa vertente, mas lidamos com elementos de um corpus organizado, e cada trabalho que é feito com a utilização de corpora específicos constitui um ganho tanto no âmbito da análise linguística em si, quanto em relação à avaliação dos procedimentos técnicos capazes de serem empreendidos nessa análise. 
Ademais, outras áreas do conhecimento humano podem ser beneficiadas de alguma maneira com a adoção do modelo proposto, desde que estejam interessadas na descrição das representações mentais envolvidas na articulação textual. Referimo-nos aqui superficialmente a algumas áreas mais ligadas à cognição humana, tais como a Psicologia, a Psicanálise, algumas vertentes da Pedagogia, a Ciência da Informação etc. Enfim, são muitas as possibilidades que se abrem a partir da adoção desse modelo, dentro e fora dos estudos linguísticos - na mesma proporção em que cada descoberta científica numa determinada área acarreta, no mínimo, muitas responsabilidades de investigação na própria área e nas suas correlatas. Não vamos nos enveredar aqui nessas possibilidades de aplicação do modelo em outras áreas, pois isso requereria conhecimentos específicos dentro das mesmas, mas lembramos que os termos "cognição" e, por extensão, "domínio cognitivo" aplicam-se muito bem a praticamente todo tipo de estudo que envolve processamento de sentido, raciocínio lógico, processos mentais, redes neurais, estados psicológicos etc. E, conforme mostramos, sendo a narração um processo inerente à espécie humana, a adoção de um modelo que considere a existência de um domínio cognitivo em que se processa a narração certamente é capaz de trazer muitos benefícios em termos de uma melhor compreensão de como funciona a mente humana.

\section{Referências}

BERBER SARDINHA, T. An assessment of metaphor retrieval methods. 2009.25 p. Draft.

. Linguística de corpus. Barueri: Manole, 2004.

BEZERRA, M. A. Da redação ao gênero textual: a didatização da escrita na sala de aula. In: MOURA, D. (Org.). Os desafios da língua: pesquisas em língua falada e escrita. Maceió: EDUFAL, 2008. p. 135-138.

FAUCONNIER, G. Espaces mentaux: aspects de la construction du sens dans les langues naturelles. Paris: Minuit, 1984.

Mappings in thought and language. Cambridge: Cambridge University Press, 1997. cross ref $\underline{\mathrm{http}: / / \mathrm{dx} . \text { doi.org/10.1017/CBO9781139174220 }}$

Mental spaces: aspects of meaning construction in natural language.

Cambridge: Cambridge University Press, 1994. crossref http://dx.doi.org/10.1017/CBO9780511624582 
FAUCONNIER, G.; TURNER, M. Blending as a central process of grammar. In: GOLDBERG, A. (Ed.). Conceptual structure, discourse, and language. Stanford: Center for the Study of Language and Information (CSLI) / Cambridge University Press, 1996. p. 113-129.

Conceptual integration networks. In: Cognitive science, vol. 22 (2), p. 133-187, 1998. cross ref $\mathrm{http://dx.doi.org/10.1207/s15516709 \operatorname {cog } 2 2 0 2 \_ 1}$

. Conceptual projection and middle spaces (1994). Report 9401. University of California, San Diego. $\quad$ Disponível em $<$ http://www.cogsci.ucsd.edu/research/files/technical/9401.pdf $>$. Acesso em: 08 fev. 2008.

2000 .

Compression and global insight. In: Cognitive Linguistics $11-3 / 4$, p. 283-304,

The way we think: conceptual blending and the mind's hidden complexities. New York: Basic Books, 2002.

GIBBS JR., R. W. A new look at literal meaning in understanding what is said and implicated. Journal of pragmatics, 34, p. 457-486, 2002 . crossref http://dx.doi.org/10.1016/S0378-2166(01)00046-7

GRADY, J. E.; OAKLEY, T.; COULSON, S. Blending and metaphor. In: GIBBS JR., R. W.; STEEN, G. J. (Eds.). Metaphor in cognitive linguistics; selected papers from the Fifth International Cognitive Linguistics Conference. Amsterdam / Philadelphia: John Benjamins Publishing Company, 1997. p. 101-124.

LAKOFF, G.; JOHNSON, M. Metaphors we live by. Chicago/London: The University of Chicago Press, 1980.

LANGACKER, R. W. Foundations of cognitive grammar, volume I - Theoretical Prerequisites. Stanford: Stanford University Press, 1987.

Foundations of cognitive grammar, volume II - Descriptive Application. Stanford: Stanford University Press, 1991.

NUNBERG, G. The pragmatics of reference. Bloomington: Indiana University Linguistics Club, 1978.

REDDY, M. J. The conduit metaphor: a case of frame conflict in our language about language. In: ORTONY, A. (Org.). Metaphor and thought. Cambridge: Cambridge University Press, 1979. p. 284-324.

STEFANOWITSCH, A. Corpus-based approaches to metaphor and metonymy. In: STEFANOWITSCH, A.; GRIES, S. T. (Eds.). Corpus-based approaches to metaphor and metonymy. Berlin/New York: Mouton de Gruyter, 2006. p. 1-16 (Trends in Linguistics 171). crossref $\underline{\mathrm{http}}$ ://dx.doi.org/10.1515/9783110199895 
. The function of metaphor. International Journal of Corpus Linguistics, 10:2, p. 161-198, 2005. cross ref $\underline{\mathrm{http}: / / \mathrm{dx} \text {.doi.org/10.1075/ijcl.10.2.03ste }}$

; GRIES, S. T. Collostructions: investigating the interaction of words and constructions. International Journal of Corpus Linguistics, 8:2, p. 209-243, 2003. crossref http://dx.doi.org/10.1075/ijcl.8.2.03ste

TURNER, M. The literary mind: the origins of thought and language. New York / Oxford: Oxford University Press, 1996.

TURNER, M.; FAUCONNIER, G. Conceptual integration and formal expression. In: JOHNSON, M. (Ed.). Journal of metaphor and symbolic activity, vol. 10, n. 3, p. 183-203, 1995.

Artigo recebido em: 14.10 .2014

Artigo aprovado em: 21.11.2014 